\title{
Adventitious Shoot Regeneration from In Vitro Leaves of Formosan Sweetgum (Liquidambar formosana L.)
}

\author{
L. Xu, G.F. Liu, and M.Z. Bao ${ }^{1}$ \\ Key Laboratory of Horticultural Plant Biology, Ministry of Education, \\ College of Horticulture and Forestry Sciences, Huazhong Agricultural \\ University, Wuhan, 430070, P.R. China
}

Additional index words. Liquidambar formosana, leaf explants, plant regeneration, organogenesis

\begin{abstract}
Plantlets were regenerated from in vitro-grown leaf explants of five genotypes of Liquidambar formosana on WPM basal medium supplemented with different concentrations of TDZ and NAA. With the addition of $0.27 \mu \mathrm{M}$ NAA, regeneration efficiency was increased by 2- to 4-fold over that with TDZ alone. Lower concentrations of TDZ $(0.45-2.27 \mu \mathrm{M})$ were beneficial for regenerating shoot clusters. Four genotypes (P2, P6, $\mathrm{P9}$, and $\mathrm{P} 11$ ) showed high regeneration rates (up to $90 \%$ ), whereas genotype $\mathrm{P} 13$ showed a low capability for shoot regeneration on all media tested $(<35 \%)$. For all five genotypes, the optimum medium for inducing adventitious shoots was WPM supplemented with $1.14 \mu_{M}$ TDZ and $0.27 \mu_{M}$ NAA, on which regeneration rate ranged from $72.6 \%$ to $89.5 \%$ and adventitious shoot clusters per regenerating leaf explant ranged from 2.63 to 3.11 in four genotypes (P2, P6, P9, and P11), while for P13, the regeneration rate and number of shoot clusters per regenerating explant were $23 \%$ and 1.39 , respectively. Transfer of shoot clusters to WPM basal medium containing $0.54 \mu \mathrm{M}$ NAA, $2.22 \mu \mathrm{M}$ BA, and $1.44 \mu \mathrm{M}$ $\mathrm{GA}_{3}$, resulted in shoot elongation. All the elongated shoots were rooted on WPM supplemented with $9.84 \mu \mathrm{M}$ IBA, and plantlets were transplanted to soil successfully. Chemical names used: 6-benzyladenine $(B A)$, gibberellic acid $\left(G A_{3}\right)$, indole-3-butyric acid (IBA), 1-naphthalene acetic acid (NAA), plant growth regulator (PGR), thidiazuron (TDZ), woody plant medium (WPM).
\end{abstract}

Formosan sweetgum (Liquidambar formosana L.), the counterpart to sweetgum (L. styraciflua L.) grown in America, is distributed in most of temperate and subtropical China. Formosan sweetgum is popular in forestry and has been employed in urban landscaping in recent years, but its spiny fruits disintegrate very slowly and create a nuisance on lawns and walks (Brunner et al., 1998). Therefore, breeding for sterility would greatly improve the usefulness of Formosan sweetgum as a landscape tree.

The long generation time of many perennial woody species results in an extended period for traditional breeding programs. Genetic transformation based on tissue culture technology provides a way to speed up the breeding of Formosan sweetgum for simply inherited traits. In L. styraciflua, plants have been regenerated via adventitious shoots from mature leaf and petiole segments (Brand and Lineberger, 1988) and hypocotyl

\footnotetext{
Received for publication 17 Oct. 2006. Accepted for publication 8 Dec. 2006.

This research was supported by the National Natural Science Foundation of China (No. 30371015).

We thank all the colleagues in our laboratory for constructive discussion and technical support.

${ }^{1}$ To whom reprint requests should be addressed; e-mailmzbao@mail.hzau.edu.cn.
}

segments (Kim et al., 1997), and via somatic embryogenesis from hypocotyl-derived callus (Sommer and Brown, 1980), immature seeds (Merkle et al., 1998), and staminate and pistillate inflorescences (Merkle et al., 1998; Merkle and Battle, 2000). In addition, Sullivan and Lagrimini (1993) transformed L. styraciflua using Agrobacterium tumefaciens (Smith et. Townsend) Conn. In Formosan sweetgum, however, data on tissue culture, especially for plant regeneration, is very limited. Vendrame et al. (2001) used thidiazuron (TDZ) to regenerate hybrid sweetgum (L. styraciflua $\times$ L. formosana) by somatic embryogenesis. Durkovic et al. (2005) reported the micropropagation of Formosan sweetgum with a novel pattern of adventitious rooting.

To genetically modify Formosan sweetgum for sterility, an excellent plant regeneration system is essential. We had adopted the regeneration method described by Brand and Lineberger (1988) for shoot regeneration from leaves of Formosan sweetgum using woody plant medium (WPM; Lloyd and McCown, 1980) containing $11.1 \mu \mathrm{M}$ 6-benzyladenine (BA) and $0.54 \mu \mathrm{M}$ 1-naphthalene acetic acid (NAA). However, results were not satisfactory. Therefore, our objective was to develop a regeneration system from leaf explants of $L$. formosana via organogenesis induced by TDZ, which could be applicable for Agrobacterium-mediated transformation.
Plant materials. Five 20-year-old trees (denoted as five genotypes: P2, P6, P9, P11, and P13) grown on the campus of Huazhong Agricultural University, Wuhan, China, were taken as experimental materials. After surface-sterilization by immersion in $70 \%(\mathrm{v} / \mathrm{v})$ ethanol for $30 \mathrm{~s}$, followed by a 6-min immersion in $0.1 \%(\mathrm{w} / \mathrm{v})$ mercuric chloride $\left(\mathrm{HgCl}_{2}\right)$ solution, and then three rinses of $3 \mathrm{~min}$ each with sterile distilled water, axillary buds were cultured on WPM basal medium containing $0.54 \mu \mathrm{M}$ NAA, $2.22 \mu \mathrm{M}$ BA, $1.44 \mu \mathrm{M}$ gibberellic acid $\left(\mathrm{GA}_{3}\right)$, and $30 \mathrm{~g} \cdot \mathrm{L}^{-1}$ sucrose in 250-mL plastic jars for establishing shoot cultures by proliferation. Each jar contained $40 \mathrm{~mL}$ of medium and was sealed with a lid. The medium was gelled with $7 \mathrm{~g} \cdot \mathrm{L}^{-1}$ agar (Sigma A1296), and the $\mathrm{pH}$ was adjusted with $1 \mathrm{M} \mathrm{NaOH}$ to 5.8 before autoclaving at $121^{\circ} \mathrm{C}$ for $20 \mathrm{~min}$. Cultures were incubated at $25 \pm$ $1{ }^{\circ} \mathrm{C}$ under a 14-h photoperiod of $50 \mu \mathrm{mol} \cdot \mathrm{m}^{-2} \cdot \mathrm{s}^{-1} P P F$ (photosynthetic photon flux) provided by $40-\mathrm{W}$ cool-white fluorescent tubes. The expanding leaves ( $8 \mathrm{~mm}$ in length) were used for adventitious shoot regeneration.

Shoot regeneration. P6 was used in the primary experiment. Expanded leaves were wounded by three transverse cuts through the midrib without severing it. All leaves were placed abaxial side down on WPM basal medium supplemented with NAA at $0,0.054,0.27$, and $0.54 \mu \mathrm{M}$, combined with TDZ at $0,0.45,2.27$, and $4.54 \mu \mathrm{M}$. Media were sterilized by autoclaving at $121{ }^{\circ} \mathrm{C}$ for $20 \mathrm{~min}$, allowed to cool, and dispensed into sterile $100 \times 15-\mathrm{mm}$ petri dishes $(25 \mathrm{~mL}$ of medium per dish). The petri dishes were incubated at $25 \pm 1{ }^{\circ} \mathrm{C}$ in darkness for $7 \mathrm{~d}$ and then transferred to light of $5-10 \mu \mathrm{mol} \cdot \mathrm{m}^{-2} \cdot \mathrm{s}^{-1}$ $P P F$ and 14-h photoperiod.

To obtain the optimal TDZ concentration for organogenesis from leaf explants of the five genotypes, on the basis of results of the initial experiment with P6, several concentrations of TDZ $(0.45,1.14,2.27,3.41$, and $4.54 \mu \mathrm{M})$ were further investigated in combination with $0.27 \mu \mathrm{M}$ NAA.

In all experiments, each plant growth regulator (PGR) treatment combination contained five replicates (petri dishes) with 10 leaf explants per replicate. Leaves were cultured for a total of 8 weeks without transfer to fresh medium, and all experiments were repeated twice. Cultures were observed weekly, and the frequency of shoot regeneration and the number of shoot clusters formed per regenerating leaf were recorded.

Shoot elongation. Regenerating leaf explants were transferred to $250-\mathrm{mL}$ plastic jars containing $40 \mathrm{~mL}$ of WPM medium supplemented with $0.54 \mu \mathrm{M}$ NAA, $2.22 \mu \mathrm{M}$ $\mathrm{BA}$, and $1.44 \mu \mathrm{M} \mathrm{GA}_{3}$ and then cultured at $25 \pm 1{ }^{\circ} \mathrm{C}$ under a 14 -h photoperiod of $50 \mu \mathrm{mol} \cdot \mathrm{m}^{-2} \cdot \mathrm{s}^{-1} P P F$

Rooting and transplanting to soil. Elongated shoots ( $2 \mathrm{~cm}$ in length) were cultured in $250-\mathrm{mL}$ plastic jars containing $40 \mathrm{~mL}$ of WPM basal medium supplemented with $9.84 \mu \mathrm{M}$ indole-3-butyric acid (IBA) and 
$30 \mathrm{~g} \cdot \mathrm{L}^{-1}$ sucrose and solidified with $7 \mathrm{~g} \cdot \mathrm{L}^{-1}$ agar. After culture for 8 weeks, the roots were cleaned of agar with tap water, and the plantlets were transplanted into pots containing sterile vermiculite and soil $(1: 2 \mathrm{v} / \mathrm{v})$, and were covered with polyethylene film for $7 \mathrm{~d}$. Plantlets were irrigated using sterile water to maintain wetness. Survival rate was recorded 4 weeks after transplanting. Surviving plants were transplanted to the field after 8 weeks and grew well.

\section{Results and Discussion}

Establishment of shoots from axillary buds. After surface-sterilization using the method described above, almost all axillary buds survived and germinated within 2 weeks. Every 4 weeks, the shoot clusters were divided into single shoots and transferred onto fresh medium.

Shoot regeneration. The first bud structures began to appear 4 weeks after culture initiation and increased over the subsequent 4 weeks. Like sweetgum (Brand and Lineberger, 1988), the petiole stump and main veins were most prolific (Fig. 1A, B).

For P6, no adventitious shoots were obtained on WPM without PGR, but a few roots developed (data not shown). Organogenesis was promoted greatly in the presence of NAA, and regeneration efficiency was increased up to 2- to 4-fold over that with TDZ alone (Table 1). The highest regeneration rate was obtained with $2.27 \mu \mathrm{M}$ TDZ in combination with $0.27 \mu \mathrm{M}$ NAA, which was twice that with TDZ alone (Table 1). This response was somewhat similar to that of L. styraciflua, where more prolific adventitious shoots were obtained on combination of 2,4-D and TDZ than with TDZ alone (Kim et al., 1997).

The response of leaf explants varied among various TDZ concentrations in combination with $0.27 \mu \mathrm{M}$ NAA. For all genotypes, the most shoots were produced at $1.14 \mu \mathrm{M}$ TDZ. Results were generally similar to those in L. styraciflua with $0.45-2.27 \mu \mathrm{M}$ TDZ (Kim et al., 1997). In L. styraciflua, most buds and shoots differentiated without any intervening callus formation, and even at 22.7 and $45.4 \mu \mathrm{M} \mathrm{TDZ}$, the number of bud primordia increased through 7 weeks of culture, although with less shoot elongation (Kim et al., 1997). But in Formosan sweetgum, higher concentrations of TDZ $(>2.27)$ resulted in excessive callus formation and fewer adventitious shoots (Tables 1, 2, and 3 ). Such a response had also been observed in silver maple (Preece et al., 1991).

Genotype significantly influenced adventitious shoot differentiation from cultured explants. Four genotypes (P2, P6, P9, and $\mathrm{P} 11)$ showed higher shoot regeneration capabilities (up to 90\%), whereas the highest shoot regeneration frequency for $\mathrm{P} 13$ was $<35 \%$ (Table 2). Although each genotype had its own optimum combination of TDZ and NAA, medium supplemented with $1.14 \mu \mathrm{M}$ TDZ and $0.27 \mu \mathrm{M}$ NAA was satisfactory for all of the genotypes (Table 2). Similar genoalso been reported in various species (Caboni et al., 1999; Liu and Bao, 2003; Merkle and Battle, 2000).

Shoot elongation and proliferation. In our study, when leaf explants were cultured at 0.45-4.54 $\mu_{\mathrm{M}}$ TDZ, adventitious shoots remained short and compact (Fig. 1A, B). When transferred to shoot proliferating media containing $0.54 \mu \mathrm{M}$ NAA, $2.22 \mu \mathrm{M}$ $\mathrm{BA}$, and $1.44 \mu \mathrm{M} \mathrm{GA}_{3}$, the regenerating shoots elongated within 4 weeks (Fig. 1C), and new shoots proliferated from basal axillary buds. TDZ has been reported to inhibit shoot elongation in several woody species (Huetteman and Preece, 1993; Lu, 1993), and extended culture with TDZ resulted in abnormal leaf morphology, and typic variation in regeneration efficiency has

compact shoots in L. styraciflua (Kim et al., 1997). A similar phenomenon was noted in this study. In the report of L. formosana by Durkovic et al. (2005), shoot elongation was observed when there was no TDZ, which is in accordance with our observation. But they did not observe fasciated shoots. Within 12 weeks of culture, elongated shoots were obtained from leaves of $L$. formosana in our study, whereas in the report by Durkovic et al. (2005), 18 weeks were needed using petiole as explants for shoot multiplication cultured on WPM containing $2.22 \mu \mathrm{M}$ BA.

Rooting and transplanting to soil. One hundred per cent of the elongated shoots rooted on WPM supplemented with $9.84 \mu \mathrm{M}$ IBA (Fig. 1D), which is in accordance with results in L. styraciflua (Kim et al., 1997).
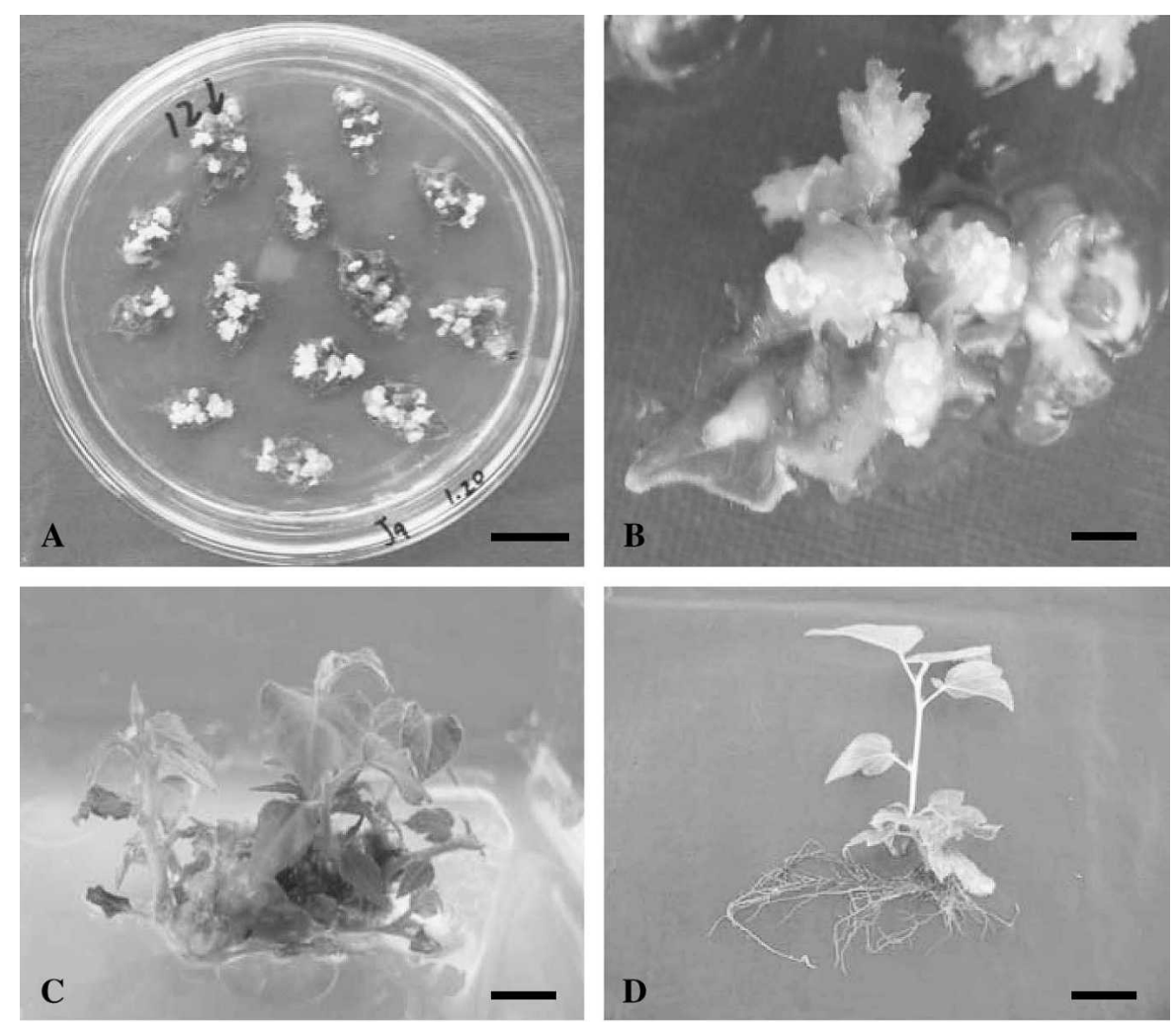

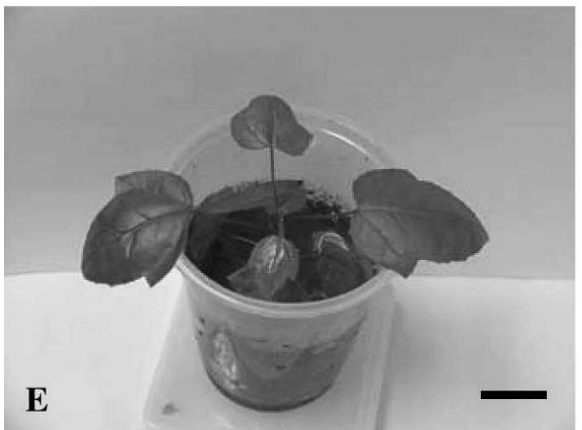

Fig. 1. Shoot regeneration from in vitro cultured leaves of L. formosana. (A) Adventitious shoot regeneration from wounded leaves, after 8 weeks of culture on induction medium (bar, $1 \mathrm{~cm})$. (B) Shoot formation on the cut end of petioles and along the cuts across the midvein of leaf explants (bar, $2 \mathrm{~mm}$ ). (C) Shoot formation on leaf explants, transferred after 4 weeks to WPM containing $0.54 \mu \mathrm{M}$ NAA, $2.22 \mu \mathrm{M} \mathrm{BA}$, and $1.44 \mu \mathrm{M} \mathrm{GA}_{3}$ (bar, $5 \mathrm{~mm}$ ). (D) Effect of $9.84 \mu \mathrm{M}$ IBA on rooting of microshoots after culture for 8 weeks (bar, $5 \mathrm{~mm}$ ). (E) Plant of L. formosana, $40 \mathrm{~d}$ after being transplanted to soil (bar, $1 \mathrm{~cm}$ ). 
Table 1. Effect of NAA and TDZ on adventitious shoot regeneration from leaf explants of L. formosana.

\begin{tabular}{llcc}
\hline Concn $(\mu \mathrm{M})$ & TDZ & $\begin{array}{c}\text { Percentage of leaf } \\
\text { explants forming shoots }\end{array}$ & $\begin{array}{c}\text { No. of shoot clusters } \\
\text { per regenerating leaf }\end{array}$ \\
\hline NAA & 0 & 0 & 0 \\
0 & 0.45 & $15.9 \pm 4.1 \mathrm{~d}$ & $1.60 \pm 0.4 \mathrm{bc}$ \\
0 & 2.27 & $34.5 \pm 1.2 \mathrm{c}$ & $1.50 \pm 0.5 \mathrm{bc}$ \\
0 & 4.54 & $17.0 \pm 1.6 \mathrm{~d}$ & $1.20 \pm 0.2 \mathrm{c}$ \\
0 & 0.45 & $57.3 \pm 1.8 \mathrm{~b}$ & $2.89 \pm 0.59 \mathrm{a}$ \\
0.054 & 2.27 & $58.8 \pm 1.3 \mathrm{~b}$ & $1.99 \pm 0.08 \mathrm{~b}$ \\
0.054 & 4.54 & $56.4 \pm 2.6 \mathrm{~b}$ & $1.85 \pm 0.01 \mathrm{~b}$ \\
0.054 & 0.45 & $66.2 \pm 7.2 \mathrm{~b}$ & $2.45 \pm 0.06 \mathrm{ab}$ \\
0.27 & 2.27 & $78.5 \pm 3.4 \mathrm{a}$ & $2.91 \pm 0.27 \mathrm{a}$ \\
0.27 & 4.54 & $67.0 \pm 0.1 \mathrm{ab}$ & $2.35 \pm 0.31 \mathrm{ab}$ \\
0.27 & 0.45 & $67.2 \pm 1.2 \mathrm{ab}$ & $2.13 \pm 0.40 \mathrm{ab}$ \\
0.54 & 2.27 & $59.6 \pm 2.5 \mathrm{~b}$ & $2.05 \pm 0.22 \mathrm{~b}$ \\
0.54 & 4.54 & $54.1 \pm 1.1 \mathrm{~b}$ & $2.07 \pm 0.13 \mathrm{~b}$ \\
0.54 & & &
\end{tabular}

Data were collected from genotype P6 after 8 weeks in culture. Values represent the mean \pm SE. Means followed by different letters are significantly different at $P=0.05$ according to the least significant difference test.

Table 2. Effect of TDZ with $0.27 \mu \mathrm{M}$ NAA on shoot cluster regeneration frequency from leaf explants of L. formosana.

\begin{tabular}{lcccccc}
\hline \multicolumn{6}{c}{ Concn $(\mu \mathrm{M})$} & \multicolumn{5}{c}{ Percentage of leaf explants forming shoots } \\
\cline { 2 - 7 } NAA & TDZ & P2 & P6 & P9 & P11 & P13 \\
\hline 0.27 & 0.45 & $71.7 \pm 5.0 \mathrm{a}$ & $65.2 \pm 7.2 \mathrm{c}$ & $63.4 \pm 3.1 \mathrm{a}$ & $57.4 \pm 7.4 \mathrm{c}$ & $17.5 \pm 2.5 \mathrm{ab}$ \\
0.27 & 1.14 & $72.6 \pm 0.4 \mathrm{a}$ & $89.5 \pm 3.5 \mathrm{a}$ & $72.8 \pm 1.4 \mathrm{a}$ & $75.0 \pm 0.9 \mathrm{~b}$ & $23.0 \pm 3.8 \mathrm{ab}$ \\
0.27 & 2.27 & $74.3 \pm 1.3 \mathrm{a}$ & $77.5 \pm 3.4 \mathrm{~b}$ & $69.6 \pm 1.7 \mathrm{a}$ & $66.7 \pm 2.2 \mathrm{bc}$ & $32.6 \pm 0.8 \mathrm{a}$ \\
0.27 & 3.41 & $53.2 \pm 3.5 \mathrm{~b}$ & $74.1 \pm 8.1 \mathrm{~b}$ & $71.7 \pm 5.0 \mathrm{a}$ & $90.0 \pm 3.6 \mathrm{a}$ & $15.0 \pm 5.0 \mathrm{~b}$ \\
0.27 & 4.54 & $41.7 \pm 0.8 \mathrm{c}$ & $68.0 \pm 0.1 \mathrm{bc}$ & $80.4 \pm 5.4 \mathrm{a}$ & $71.8 \pm 5.1 \mathrm{~b}$ & $12.9 \pm 6.2 \mathrm{~b}$ \\
\hline
\end{tabular}

Data were collected from five genotypes P2, P6, P9, P11, and P13 after 8 weeks in culture. Values represent the mean \pm SE. Means followed by different letters are significantly different at $P=0.05$ according to the least significant difference test.

Table 3. Effect of TDZ with $0.27 \mu \mathrm{M}$ NAA on the number of shoot clusters per regenerating leaf explant of L. formosana.

\begin{tabular}{|c|c|c|c|c|c|c|}
\hline \multicolumn{2}{|c|}{ Concn $(\mu \mathrm{M})$} & \multicolumn{5}{|c|}{ No. of shoot clusters per regenerating leaf } \\
\hline NAA & TDZ & P2 & P6 & P9 & P11 & P13 \\
\hline 0.27 & 0.45 & $2.31 \pm 0.69 \mathrm{ab}$ & $2.37 \pm 0.06 \mathrm{ab}$ & $3.77 \pm 0.48 \mathrm{a}$ & $2.70 \pm 0.53 \mathrm{a}$ & $1.25 \pm 0.2$ \\
\hline 0.27 & 1.14 & $3 \pm 0.01$ & \pm 0.4 & $2.64 \pm 0$. & $7 \pm 0$ & 0.0 \\
\hline 0.27 & 2.27 & $1.94 \pm 0.01 \mathrm{abc}$ & $2.92 \pm 0.27 \mathrm{a}$ & $2.47 \pm 0.48 \mathrm{~b}$ & $2.13 \pm 0.38 \mathrm{a}$ & $1.10 \pm 0.10$ \\
\hline 0.27 & 3.41 & $1.13 \pm 0.26 \mathrm{c}$ & $2.21 \pm 0.18 \mathrm{~b}$ & $2.06 \pm 0.45 \mathrm{~b}$ & $2.10 \pm 0.23 \mathrm{a}$ & $1.00 \pm 0.00$ \\
\hline 0.27 & 4.54 & $1.40 \pm 0.53 \mathrm{bc}$ & $2.17 \pm 0.31 \mathrm{ab}$ & $2.02 \pm 0.27 \mathrm{~b}$ & $2.15 \pm 0.15 \mathrm{a}$ & $1.00 \pm 0.00$ \\
\hline
\end{tabular}

Data were collected from five genotypes P2, P6, P9, P11, and P13 after 8 weeks in culture. Values represent the mean $\pm \mathrm{SE}$. Means followed by different letters are significantly different at $P=0.05$ according to the least significant difference test.

All adventitious roots differentiated at the base of the shoot. Aerial adventitious rooting, which occurred in L. formosana as reported by Durkovic et al. (2005), was not observed in our study. The rooted plantlets were transplanted to soil and grew normally outdoors (Fig. 1E). More than 90\% survived. After 9 months' observation, the transplanted plants were uniform and no phenotypic variation was found.
This study is the first report of shoot regeneration from in vitro cultured leaves of L. formosana. The efficient regeneration protocol from leaves of in vitro cultures obtained from mature trees, which is applicable to many genotypes, provides a prerequisite for further transformation for seed-sterility through expression of an exogenous gene or suppression of an endogenous gene in this woody species.

\section{Literature Cited}

Brand, M.H. and R.D. Lineberger. 1988. In vitro adventitious shoot formation on mature-phase leaves and petioles of Liquidambar styraciflua L. Plant Sci. 57:173-179.

Brunner, A.M., R. Mohamed, R. Meilan, L.A. Sheppard, W.H. Pottman, and S.H. Strauss. 1998. Genetic engineering of sexual sterility in shade trees. J. Arboricult. 24:263-272.

Caboni, E., M.G. Tonelli, P. Lauri, S.D. Angeli, and C. Damiano. 1999. In vitro shoot regeneration from leaves of wild pear. Plant Cell Tissue Org. Cult. 59:1-7.

Durkovic, J., V. Pichler, and A. Lux. 2005. Micropropagation with a novel pattern of adventitious rooting in Formosan sweetgum. Can. J. For. Res. 35:2775-2780

Huetteman, C.A. and J.E. Preece. 1993. Thidiazuron: a potent cytokinin for woody plant tissue culture. Plant Cell Tissue Org. Cult. 33:105-119.

Kim, M.K., H.E. Sommer, B.C. Bongarten, and S.A. Merkle. 1997. High-frequency induction of adventitious shoots from hypocotyl segments of Liquidambar styraciflua L. by thidiazuron. Plant Cell Rpt. 16:536-540.

Liu, G.F. and M.Z. Bao. 2003. Adventitious shoot regeneration from in vitro cultured leaves of London plane tree (Platanus acerifolia Willd.). Plant Cell Rpt. 21:640-644.

Lloyd, G.B. and B.H. McCown. 1980. Commercially feasible micropropagation of mountain laurel, Kalmia latifolia, by use of shoottip culture. Proc. Int. Plant Prop. Soc. 30: 421-427.

$\mathrm{Lu}, \mathrm{C.Y} .1993$. The use of thidiazuron in tissue culture. In Vitro Cell. Dev. Biol. 19:92-96.

Merkle, S.A. and P.J. Battle. 2000. Enhancement of embryogenic culture initiation from tissues of mature sweetgum trees. Plant Cell Rpt. 19:268-273.

Merkle, S.A., K.A. Neu, P.J. Battle, and R.L. Bailey. 1998. Somatic embryogenesis from immature and mature tissues of sweetgum (Liquidambar styraciflua). Plant Sci. 132: 169-178.

Preece, J.E., C.A. Huetteman, W.C. Ashby, and P.L. Roth. 1991. Micro- and cutting propagation of silver maple. I. Results with adult and juvenile propagules. J. Amer. Soc. Hort. Sci. 116:142-148.

Sommer, H.E. and C.L. Brown. 1980. Embryogenesis in tissue cultures of sweetgum. For. Sci. $26: 257-260$

Sullivan, J. and L.M. Lagrimini. 1993. Transformation of Liquidambar styraciflua using Agrobacterium tumefaciens. Plant Cell Rpt. 12:303-306.

Vendrame, W.A., C.P. Holliday, and S.A. Merkle. 2001. Clonal propagation of hybrid sweetgum (Liquidambar styraciflua $\times$ L. formosana) by somatic embryogenesis. Plant Cell Rpt. 20:691-695. 